"The impact of macroeconomic factors on the real estate investment trust index return on Japan, Singapore and China"

\begin{tabular}{ll} 
AUTHORS & $\begin{array}{l}\text { Hao Fang } \\
\text { Tsang-Yao Chang } \\
\text { Yen-Hsien Lee } \\
\text { Wei-Jui Chen }\end{array}$ \\
& $\begin{array}{l}\text { Hao Fang, Tsang-Yao Chang, Yen-Hsien Lee and Wei-Jui Chen (2016). The } \\
\text { impact of macroeconomic factors on the real estate investment trust index return } \\
\text { on Japan, Singapore and China. Investment Management and Financial } \\
\text { Innovations, } 13(4-1), 242-253 . \text { doi:10.21511/imfi.13(4-1).2016.11 }\end{array}$ \\
ARTICLE INFO & $\begin{array}{l}\text { http://dx.doi.org/10.21511/imfi.13(4-1).2016.11 } \\
\text { DOI }\end{array}$ \\
\hline RELEASED ON & Thursday, 29 December 2016 \\
\hline JOURNAL & "Investment Management and Financial Innovations" \\
\hline FOUNDER & LLC “Consulting Publishing Company "Business Perspectives"
\end{tabular}

NUMBER OF REFERENCES

0

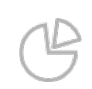

NUMBER OF FIGURES

0

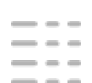

NUMBER OF TABLES

0

(C) The author(s) 2023. This publication is an open access article. 
Hao Fang (Taiwan), Tsang-Yao Chang (Taiwan), Yen-Hsien Lee (Taiwan), Wei-Jui Chen (Taiwan)

\title{
The impact of macroeconomic factors on the real estate investment trust index return on Japan, Singapore and China
}

\begin{abstract}
This study contributes to the existing literature by combining the multiple methods to clarify the influence of the macroeconomic factors on the real estate investment trust (REIT) index in three Asian countries. The authors, first, use an autoregressive distributed lag (ARDL) bounds test to find that a long-run equilibrium exists between the REIT index and the interest rate, inflation rate, and stock index for China and Singapore. The authors, then, analyze the long- and short-run elasticity of the macroeconomic variables on the REIT index. Finally, using the Granger non-causality test, the authors demonstrate that a unidirectional relationship, in which inflation-rate shifts cause REIT index changes, exists in Japan and Singapore and that a wealth effect, in which stock index movements cause REIT index changes, exists in Singapore. The findings have economic implications for investors seeking to gain from REITs using macroeconomic factors.
\end{abstract}

Keywords: REITs, macroeconomic factor, ARDL bounds test, ARDL long-run model, error-correction model, Granger non-causality test.

JEL Classification: C22, G11, L85, D53, C58, F14.

\section{Introduction}

Compared with real estate stocks, real estate investment trusts (REITs) can diversify risk by acquiring varied investment portfolios and can therefore demonstrate a stable investment return. Recently, anti-inflationary REIT commodities have become a popular investment option due to low market interest rates, continuous inflation, an improved investment environment and investmentfriendly laws and regulations. Thao (2006) indicates that asset management companies believe that the market value of the global REITs market will exceed US\$ 1,000 billion, demonstrating that global investors' affection for REITs has become a trend. REIT is like an indicator of securitized real estate, especially nonresidential real estate (NRRE). REIT, although a small share of the total stock market capitalization, provides us with a simple indicator of the "market valuation" of NRRE (see Chang et al., 2011; Davis and Zhu, 2005). Chang et al. (2011) propose that the underlying assets of REITs are mostly commercial real estate such as office buildings, shopping centers, and warehouses. Hence, it is not difficult to assess the value of NRRE through REITs. Davis and Zhu (2005) find that the results for residential real estate are consistent with those for commercial real estate. Several studies have been done to demonstrate how NRRE behave. Chen and Leung (2008) show that residential real estate (RRE) and NRRE Granger-cause each other in both Japan and Hong Kong. Davis and Zhu (2005) find

(c) Hao Fang, Tsang-Yao Chang, Yen-Hsien Lee, Wei-Jui Chen, 2016. Hao Fang, Department of Assets and Property Management, Hwa Hsia University of Technology, Taiwan.

Tsang-Yao Chang, Department of Finance, Feng Chia University, Taiwan.

Yen-Hsien Lee (Corresponding Author), Department of Finance, Chung Yuan Christian University, Taiwan.

Wei-Jui Chen, Department of Finance, Chung Yuan Christian University, Taiwan. that declining commercial property prices (CPP) lead to declining loan growth as well as wider interest margins and lower bank profitability, which may entail credit rationing. Equally, we see that decreasing CPP are strongly significant indicators of increasing non-performing loans (NPLs) and loan provisions. Kan et al. (2004) provide city-level evidence from the US that REE and NRRE co-move in the short run. Namely, each of the lagged, contemporary, and forward commercial property prices is positively correlated with residential property prices. The contemporaneous covariance between the two property prices is larger than the lagged covariance. In addition, output growth is positively correlated with the two property prices.

Correct predictions of price tendencies in REIT markets require acute observations of investors and accurate judgements regarding the macroeconomic environment and the performance of individual investments. In particular, judgements of accurate investment opportunities rely on macroeconomic assessments. Since REIT is a proxy for the underlying NRRE, macroeconomic factors should have an impact on REIT return. Using various empirical methods, many scholars have demonstrated that macroeconomic variables significantly influence the returns of REITs; however, different variables have been identified that significantly influence these returns, and the direction of the influence of these variables is frequently unclear.

For instance, Chan, Hendershott and Sanders (1990) use the multifactor pricing model to determine that unexpected inflation and interest rate risk are the main factors that influence the returns of equity REITs; these factors are responsible for up to $60 \%$ of the variance in these returns. West and Worthington (2006) use the GARCH-M approach to empiri- 
cally demonstrate that the macro-economy exhibits a significantly positive relationship with the return of REITs and that certain variables, such as the long-run interest rate, the short-run interest rate, unexpected inflation and the construction index, demonstrate particularly high correlations with commercial real estate returns. Hoesli and Reka (2015) empirically show that there exists the risk of contagion between REITs and stocks in the United States. They further find that this phenomenon is driven by behavioral mechanism of investor sentiment and liquidity dynamics (e.g., funding liquidity). The results of Huang and Wu (2015) show that, by considering REIT-stock extreme dependences, investors are willing to pay switching fees to change their asset-allocation strategies. Meanwhile, they find that interest rates have significant explanatory powers in the REIT-stock dependences, and they significantly influence the other determinants. Among the macroeconomic variables that have been examined in previous studies, the interest rate, the inflation rate and the stock price index has produced the most significant influence on the returns of REITs respectively.

Although several scholars believe that interest rate is not correlated with the performance of REITs (e.g., Bredin, O'Reilly and Stevenson, 2008; Lin, 2004; Mueller and Pauley, 1995), most relevant studies have observed that the interest rate is negatively related to REIT performance (e.g., Peiser and Smith, 1985; Chan et al., 1990; McCue and Kling, 1994; Jacob and Zisler, 1994; Chen and Tzang, 1998; Karolyi and Sanders, 1998; Allen, Madura and Springer, 2000; Devaney, 2001; Swanson, Theis, and Casey, 2002; Glascock, Lu and So, 2002; $\mathrm{He}$, Webb, and Myer, 2003; Conner and Liang, 2005). For instance, Allen et al. (2000) find strong evidence that the return of REITs is sensitive to changes in short- and long-run interest rates. Devaney (2001) uses the GARCH model to examine the influence of changes in interest rates on the abnormal returns of REITs and demonstrates that the yield of government bonds has a significantly negative relationship with the returns of equity and mortgage REITs. Through regression analysis, Conner and Liang (2005) empirically determine that the asset income growth rate and interest rate strongly and directionally influence real estate returns. Furthermore, the existence of causal relationships between interest rates and the performance of REITs has been investigated by scholars such as Allen et al. (2000), Glascock et al. (2002), He et al. (2003), and Liow (2006). Thus, the first hypothesis of the impact of macroeconomic factors on REIT index return has been assumed as that the interest rate negatively affects the REIT index return.
A few scholars claim that inflation does not have a significant influence on the returns of REITs ( $\mathrm{Lu}$ and So, 2001; Simpson, Ramchander and Webb, 2007; Kim, Leatham and Bessler, 2007), while some scholars continue to believe that inflation is positively related to the performance of REITs (e.g., Chan et al., 1990; Chen, Hsien, and Jordan, 1997; Payne, 2003). However, most researchers believe that inflation is negatively related to the performance of REITs (Gyourko, and Linneman, 1998; Chatrath and Liang, 1998; Glascock et al., 2002; Ewing and Payne, 2005; Adrangi, Chatath and Raffiee, 2004; Hideki, 2007). Using the VAR model, Ewing and Payne (2005) empirically determine that inflation produces lower expected returns for REITs. Adrangi et al. (2004) empirically demonstrate that the returns of REITs are negatively related to the inflation rate; in other words, the returns of REITs cannot effectively defend against inflation during inflationary periods. Thus, the second hypothesis of the impact of macroeconomic factors on REIT index return has been assumed as that the inflation rate negatively affects the REIT index return.

Mengden and Hartzell (1986), Ross and Zisler (1987a; 1987b; 1991), Ennis and Burik (1991), Gyourko and Keim (1992), Liu and Mei (1992), Li and Wang (1995), Peterson and Hsieh (1997), and Karolyi and Sanders (1998) demonstrate that stock price indices exhibit highly positive relationships with the returns of REITs indices. In particular, Li and Wang (1995) verify that the stock market return is related to the market returns of REITs. Peterson and Hsieh's (1997) research on the monthly returns of American equity and mortgage REITs indicates that the risk factors that affect the returns of mortgage REITs are related to a subset of the factors that affect stock market and bond returns.Karolyi and Sanders (1998) use the multifactor asset pricing model to conduct research on the process of generating REIT returns. The results of Huang, Wu, Liu and $\mathrm{Wu}$ (2016) show that, as the global financial crisis occurred, there are high REIT-stock linkages and few diversification opportunities. Liow, Zhou and $\mathrm{Ye}$ (2015) indicate that there are reasonable correlation dependences between real estate securities and stock markets. Then, the simultaneous relationships between stock markets and real estate securities markets can be analysed by including each national stock market in the correlation model.

These researchers' results indicate that the risk factors for the stock and bond market also affect REIT returns. Hence, the third hypothesis of the impact of macroeconomic factors on REIT index return has been assumed as that the stock price index positively affects the REIT index return. In sum, this study uses a multi-dimensional approach to analyse 
whether there are co-integration relationships among the nominal interest rate, the inflation rate, the stock price index and the REIT index as well as the causality of these relationships. Moreover, we clarify whether these three macroeconomic variables have significant influences on the REIT index returns, and what the extent and direction of the influences are.

Because the three macroeconomic variables are a mix of $\mathrm{I}(0)$ and $\mathrm{I}(1)$, this study adopts the autoregressive distributed lag (ARDL) bounds test developed by Pesaran et al. (2001) to examine the cointegration relationships between these variables and the REIT index. This approach may be superior to other conventional cointegration assessments because it allows us to overcome the problems that may result from the uncertainties of unit root test results, endogenous problems among the examined variables and a small sample size. Moreover, to analyse the long- and short-run elasticity of the macroeconomic variables on the REIT index, this study separately estimates an ARDL long-run model and an error correction model (ECM). The former method enables us to clarify whether all of the estimated coefficients are statistically significant and whether each estimated coefficient is positive or negative; thus, this method helps us resolve the inconsistencies that have been observed in the results from previous studies of this topic. By contrast, the ECM method presents the short-run correct sign, which may deviate from the long-run equilibrium, and indicates whether the feedback mechanism of reverting to the equilibrium is effective. This study uses the Granger non-causality test proposed by Toda and Yamamoto (1995) to examine the causal relationship between the respective macroeconomic variables and REIT index. The use of this method obviates the need to assess whether the examined variables are $\mathrm{I}(0)$ or $\mathrm{I}(1)$ and the cointegration properties of these variables.

In recent years, some countries in Europe have undergone a credit crisis, worldwide economic growth has generally been slow, the quantitative easing monetary policy has been implemented extensively in the US, and global funds have continued to flow into the Asian market. In particular, international funds have influenced China, the largest emerging market in Asia. For this reason, this study focuses on the analysis of Asian REITs. Asian countries have successively issued real estate securitisation funds since 2001. The vigorous development of REITs in this region can be observed from the fact that the top three Asian countries account for larger market value and the recent rapid growth of REITs in Asian. After the recent recovery of the Japanese economy, domestic demand drove a real estate boom, and individuals, institutions and foreign investors surged into the Japanese real estate market, contributing to its vigorous growth. The occupancy rate and rent of office buildings and shopping centres in Singapore are maintained at high levels because this nation is densely populated; thus, the dividends of REITs in Singapore have remained high. Chen et al. (2014) suggest that Japanese and Singaporean REITs were based on the Australian market that was predominantly managed after the early US REIT market.

The Chinese economy has developed vigorously in recent years, and the Chinese REIT market is expected to grow very rapidly. The annual average economic growth rate in China since 2000 has been $11.45 \%$. Liow and Newell (2012) believe that the three Greater China (hereafter, GC) real estate securities markets have drawn great attention from international fund managers in recent years, especially as China continues to develop both in Asia and internationally. Overall, the results indicate that the three GC markets are integrated among themselves as well as with the US markets. The conditional correlations among the GC markets have outweighed their conditional correlations with the US market. Wang, Sun, and Chen (2009) suggest that Chinese pension funds and retirees would also be particularly appropriate investors for Chinese REITs. This is because a growing proportion of China's population is reaching retirement age. Given the preference of retirees and pension plan originators for low-risk and stable income investments, the characteristics of Chinese REITs appropriately align with these investors' needs. The Chinese market also demands REITs to help reduce risk to banks. According to a DTZ estimate, the total value of property assets held by investors in China amounted to US\$1.1 trillion in 2010-in second regional position just behind Japan. That translates as one-third of the total investment in Asia and almost $10 \%$ of that in the world. One-third of this amount involves property (Dubach, 2013). Quek and Ong (2008) deem that other drivers of REITs in China include a large pool of quality real estate assets, strong potential demand from Chinese institutional investors, and the ability of REITs to stimulate a better-regulated property market in China through other real estate professional services. The success of a REIT listing in China will be beneficial to both Chinese developers as well as the overall property market. Hence, one of our contributions is that our sample choice in the REIT markets results from the managerial model in the Asia-Pacific region and the growth of the GC market. An analyst from the United Bank of Switzerland has observed that Asian real estate is undervalued, and has excellent pros- 
pects to continue booming in the future; REITs, therefore, remain a top investment option.

There is some empirical evidence in recent literature to show that the relationship between REIT returns and macroeconomic variables is linear (Chen et al., 2012; Ewing and Payne, 2005; Downs et al., 2003; Ooi and Liow, 2004). Among them, Chen, Peng, Shyu, and Zeng (2012) use the quantile regression and OLS model at monthly frequency to investigate the effect of changes in monetary policy and macroeconomic variables (such as inflation) on US equity real estate investment trust (EREIT) returns in lower and higher return ranges. Their findings show that the impact of inflation on EREIT returns is significantly negative. Ewing and Payne (2005) utilize the technique of generalized impulse response analysis of VAR models to find that a sudden monetary tightening raised real interest rates and thus, adversely affected REIT returns. Moreover, inflation resulted in lower REIT returns. Downs, Fung, Patterson, and Yau (2003) use a VAR methodology to investigate how financial and economic variables affect the movement of REIT income and price returns. Their results show that the income- and price-return volatilities of EREITs exhibit the greatest sensitivity to changes in economic variables. Using panel regressions, Ooi and Liow (2004) identify determinants of the riskadjusted returns of real estate securities traded in these markets. The empirical results suggest that size, book-to-market value, capital structure, and market diversification have significant influence on the cross-sectional variations in real estate returns. Hence, this study adopts the multiple methods based on a linear model to explore this issue in greater depth. In detail, this study uses the ARDL bounds test and the Granger non-causality test to separately explore whether there are co-integration relationships between the REIT index and the nominal interest rate, inflation rate, and stock price index in each of these three Asian countries that have larger market values and rapid growth of REITs and what their causation is in these nations. Finally, we use the ARDL long-run model and the error correction model (ECM) to analyse the long- and short-run flexibility of the three examined macroeconomic variables on the REIT index in these three Asian countries. Through these analyses, we hope to provide relevant information that not only guides governments of these regions in making investment decisions but also provides guidelines for Asian investors to plan their investments in REITs.

\section{Data range and analysis}

Our empirical data span three Asian countries with REITs with relatively high market value and rapid growth: Japan, Singapore and China. Among these three Asian countries, Japan and Singapore have the largest REIT markets in Asia, and China has demonstrated the most rapid growth in REIT markets among Asian nations (see Table 1). Because the REIT index datasets for these three Asian countries have different beginning dates, this study considers the beginning of the REIT index for China as the beginning of the REIT index for each country since the beginning date of this index in China is shortest among these countries. Also, the REIT index datasets for these countries only have monthly data. Thus, this study uses monthly data from March 2008 to July 2012. All REIT indices and their corresponding macroeconomic variables were obtained from Datastream. The REIT index in Japan is compiled by the Tokyo Stock Exchange (TSE), while the REIT indices in Singapore and China are all compiled by the MSCI (Morgan Stanley Capital International Index) company. Each of these quantities was transformed by taking its natural logarithm and its first difference prior to analysis. Table 2 provides summary statistics. The results for the summary statistics in Table 2 reveal that the average REIT return in Singapore is higher than the average REIT returns of the other two examined nations; this phenomenon may reflect the extremely high occupancy rates and rents of office buildings and shopping centres in Singapore. Chinese REITs are the most volatile of the REITs that are examined in this study. The REIT return in China has been accompanied by large price fluctuations partly because of the recent economic changes that have occurred in this nation. ${ }^{1}$ Moreover, the Jarque-Bera test results of the REIT returns are all significantly different from zero, indicating that the REIT returns in these areas do not conform to a normal distribution.

The summary statistics for the returns of the three examined macroeconomic variables in these three Asian countries are reported in Table 2. These statistics reveal that the average stock index return in Singapore is significantly higher than the average stock index return in the other two studied countries and that this return demonstrates a higher standard deviation in China than in the other two studied countries. We also find that among the three examined Asian nations, Singapore features the greatest changes in interest rates and the highest fluctuations in these rates. Moreover, among the three examined Asian nations, China features the greatest changes in inflation rates and the highest fluctuations in these rates. These data indicate that changes in mac-

\footnotetext{
${ }^{1}$ With respect to skewness coefficients, the REIT returns in Japan and Singapore are left-skewed, whereas the REIT returns in China are right-skewed. With respect to kurtosis coefficients, the REIT returns in all of the examined nations exhibit leptokurtosis, indicating that the probability of extreme values occurring in the REIT indices in these countries are all high.
} 
roeconomic variables in Singapore and China have been extremely rapid in recent years ${ }^{2}$. Although changes in the inflation rate in Japan, Singapore and China and changes in the interest rate in China are insignificant, the Jarque-Bera test results for changes in the remaining macroeconomic variables in the other examined countries are all significantly different from zero, indicating that changes in these three macroeconomic variables in most countries do not conform to normal distributions.

\section{Methodology}

2.1. Bounds test for cointegration in the relationships between the examined macroeconomic variables and the REIT Index. Previous studies that identify macroeconomic variables with significant influences on REIT indices may be summarised as follows. Most relevant studies haveindicated that the interest rate is negatively related to the REIT index (Peiser and Smith, 1985; Chan et al., 1990; McCue and Kling, 1994; Jacob and Zisler, 1994; Chen and Tzang, 1998; Karolyi and Sanders, 1998; Allen et al., 2000; Devaney, 2001; Swanson et al., 2002; Glascock et al., 2002; He et al., 2003; Conner and Liang, 2005). Moreover, most scholars have claimed that the inflation rate is also negatively related to the REIT index (Chatrath and Liang, 1998; Glascock et al., 2002; Ewing and Payne, 2003; Adrangi et al., 2004; Hideki, 2007). Moreover, Mengden and Hartzell (1986), Ross and Zisler (1987a; 1987b; 1991), Ennis and Burik (1991), Gyourko and Keim (1992), Liu and Mei (1992), Li and Wang (1995), Peterson and Hsieh (1997), and Karolyi and Sanders (1998) have all demonstrated that the stock index has a highly positive relationship with the REIT index. Thus, this study summarises the results of previously published literature and establishes the significant relationships between macroeconomic variables and the REIT index in the following way:

$$
\begin{aligned}
& \ln R_{t}=a_{0}+a_{1 i} \ln I T_{t}+a_{2 i} I F_{t}+a_{3} \ln S_{t}+e_{t}, \\
& \Delta \ln R_{t}=\alpha_{0}+\sum_{i=1}^{p} \alpha_{1 i} \Delta \ln R_{t-i}+\sum_{i=0}^{p} \alpha_{2 i} \Delta \ln I T_{t-i}+\sum_{i=0}^{p} \alpha_{3} \Delta I F_{t-i}+\sum_{i=0}^{p} \alpha_{4} \Delta \ln S_{t-i}+ \\
& +\alpha_{5} \ln R_{t-1}+\alpha_{6} \ln I T_{t-1}+\alpha_{7} I F_{t-1}+\alpha_{8} \ln S_{t-1}+\varepsilon_{t},
\end{aligned}
$$

where ${ }^{2} \Delta \ln R, \Delta \ln I T$, and $\Delta \ln S$ are the first differences of the natural logs for the REIT index (R), interest rate (IT), and stock index (S), respectively, and $\Delta I F$ is the first difference of the inflation rate (IF).

This paper follows the procedure specified by Pesaran et al. (2001) for the bounds test to examine

\footnotetext{
${ }^{2}$ With respect to skewness coefficients, changes in inflation rates in Singapore and Japan are right-skewed, whereas changes in other macroeconomic variables in the examined nations are left-skewed. With respect to kurtosis coefficients, changes in each of the three macroeconomic variables.
}

where $\ln$ is the natural $\log , \mathrm{R}$ is the REIT index, IT is the interest rate, IF is the inflation rate, $\mathrm{S}$ is the stock price, e is the error term, and $t$ is the time. In the equation above, IF is defined as the first difference of the natural log for the consumer price index.

According to economic theory, the long-term period is typically defined as a period longer than four or five years (Atkinson, 1969). The sample period in this study ranges between four and five years (53 months), which is close to the long-term period defined for an economic model. Hence, we first examine the long-term relationship between macroeconomic variables and the REIT index. Specifically, this paper uses the ARDL bounds test proposed by Pesaran et al. (2001) to test for cointegration because this approach presents several obvious advantages over other conventional cointegration tests, as mentioned by Emran et al. (2007). First, the bounds test approach can be used regardless of whether the variable series are I(0) or I(1). Thus, the uncertainties that are raised by the unit root test can be avoided. Second, the bounds test can be readily adjusted to address the possible problem of endogeneity in explanatory variables. Third, the bounds test can be applied to studies with a small sample size, whereas, as discussed by Mah (2000), the ECM and Johansen (1988) approaches are not suitable for studies with small sample sizes. As observed by Harris (1995), the other conventional cointegration tests are also difficult to apply in small samples with poor size and power properties. In addition, the approach of this study allows for simultaneous estimations to be completed for both short- and long-run relationships. Because we have a small sample size and our explanatory variables are a mix of $\mathrm{I}(0)$ and $\mathrm{I}(1)$, the cointegration relationship for the macroeconomic variables on the REIT index is estimated by the bounds test, as in the following unrestricted error correction model

the existence of a long-run relationship among the variables that are specified in equation (2). We use the F-statistic to perform an analysis of the joint significance of the coefficients for the lagged variables of the UECM. The null and alternative hypotheses with and without the lagged variables are as follows:

$$
\begin{aligned}
& H o: \alpha_{5}=\alpha_{6}=\alpha_{7}=\alpha_{8}=0 \\
& H a: \alpha_{5} \neq \alpha_{6} \neq \alpha_{7} \neq \alpha_{8} \neq 0
\end{aligned} \text {. }
$$


For a given significance level of $\alpha$, if the computed F-statistic is higher (lower) than the upper (lower) critical bound value, then the null hypothesis of no cointegration is rejected (accepted). However, if the computed F-statistic falls within the upper and lower critical bounds, a conclusive inference cannot be obtained. Thus, the order of integration for the underlying explanatory variables is required to obtain a conclusion.
2.2. Long-run and Short-run Elasticity: the Long-run ARDL Model and the Short-run Error Correction Model. When a long-run relationship among the previous variables has been established, a conditional long-run ARDL model for the REIT index can be estimated to analyse the long-run el asticity of macroeconomic variables on the REIT index. The conditional ARDL model for the longrun impact of these variables on the REIT index is based on the following equation ${ }^{3}$ :

$\ln R_{t}=b_{0}+\sum_{i=1}^{p} b_{1 i} \ln R_{t-i}+\sum_{i=0}^{p} b_{2 i} \ln I T_{t-i}+\sum_{i=0}^{p} b_{3} I F_{t-i}+\sum_{i=0}^{p} b_{4} \ln S_{t-i}+e_{t}$.

Thus, based on this estimate of the long-run ARDL model, we can further estimate the error correction models to determine the short-run elasticity between the explanatory variables and REIT index. The error correction model for this purpose can be estimated as follows ${ }^{4}$ :

$$
\Delta \ln R_{t}=c_{0}+\sum_{i=1}^{p} c_{1 i} \Delta \ln R_{t-i}+\sum_{i=0}^{p} c_{2 i} \Delta \ln I T_{t-i}+\sum_{i=0}^{p} c_{3} \Delta I F_{t-i}+\sum_{i=0}^{p} c_{4} \Delta \ln S_{t-i}++c_{5} e c m_{t-1}+\varepsilon_{t} .
$$

2.3. The Granger Non-Causality Test of Toda and Yamamoto (1995). To test the relationship between the respective macroeconomic variables and the REIT index, this paper uses the Granger non-causality test developed by Toda and Yamamoto (1995). As proposed by Zapata and Rambaldi (1997), the advantage of this approach is that the cointegration properties of system variables do not need to be examined. Additionally, if the order of

$$
\begin{aligned}
& \ln R_{t}=\beta_{0}^{1}+\sum_{i=1}^{K+d \max } \beta_{1 i}^{1} \ln R_{t-i}+\sum_{i=1}^{K+d \max } \beta_{2 i}^{1} \ln I T_{t-i}+\varepsilon_{t}, \\
& \ln I T_{t}=\beta_{0}^{2}+\sum_{i=1}^{K+d \max } \beta_{1 i}^{2} \ln I T_{t-i}+\sum_{i=1}^{K+d \max } \beta_{2 i}^{2} \ln R_{t-i}+\varepsilon_{t} .
\end{aligned}
$$

In equation (5-1), the hypothesis that the interest rate is not a Granger cause for the REIT index is tested as follows: $H_{0}: \beta_{2 i}^{1}=0, i=1,2, \ldots, K$. Alternatively, in equation (5-2), the hypothesis that the REIT index is not a Granger cause of the interest rate is tested as follows:

$$
H_{0}: \beta_{2 i}^{2}=0, i=1,2, \ldots, K \text {. }
$$

\section{Empirical Results ${ }^{345}$}

\subsection{The Results of the Bounds Test for Cointe-} gration. The results of the bounds test for cointe-

\footnotetext{
${ }^{3}$ In this equation, all of the variables are defined in accordance with their definitions in previous equations, and the lag length in this model is determined by the Akaike information criterion or Schwarz's Bayesian criterion.

${ }^{4}$ In this equation, ecm indicates the error correction term, and $c_{5}$ measures the speed of adjustment to equilibrium.

${ }^{5}$ In this equation, $\ln R_{\mathrm{t}}$ and $\ln I T_{\mathrm{t}}$ are defined in accordance with their definitions in previous equations, $\mathrm{k}$ is the optimal lag length, and $d$ max is the maximum order of integration of the process.
}

integration in the system does not exceed the fitted lag length of the model, this approach can be utilised regardless of whether a series is $\mathrm{I}(0), \mathrm{I}(1)$ or I(2) (see Toda and Yamamoto, 1995; Caporale and Pittis, 1999). For instance, using the REIT index and interest rate as an example, we extend the approach of Toda and Yamamoto to establish the Granger non-causality test as follows ${ }^{5}$ : gration are reported in Table $3^{6 .}{ }^{6}$ The results for the AIC and SBC consistently demonstrate that the computed F-statistic for the relationships between the examined macroeconomic variables and the REIT index were greater than the critical upper bound values at the $5 \%$ and $10 \%$ levels of significance for China and Singapore, whereas the computed F-statistic did not exceed the critical upper bound values at any level of significance for Japan. These results indicate that cointegration relationships exist between the examined macroeconomic variables and the REIT index for China and Singapore over our sample period, but no similar longrun equilibrium exists for Japan. It is possibly because the long-run relationship between these macroeconomic variables and the REIT index in Japan is not fixed and could occur in the specific situation

\footnotetext{
${ }^{6}$ To confirm that the optimal lag order of the underlying UECM of equation (2) is chosen appropriately, this paper first uses the Akaike information criterion (AIC) and Schwarz's Bayesian criterion (SBC) to select the optimal lag order such that the disturbance terms of the UECM are not serially correlated.
} 
due to the fact that Japan is a developed country. Thus, the cointegration equilibrium between these variables in Japan could not occur in the entire regime.

3.2. The results for the long- and short-run elasticity. We use the long-run ARDL model specified by equation (3) to estimate the long-run elasticities for the variables of this model. ${ }^{7}$ As presented in Table 4, the results of this process consistently indicate that the lags of the explained variables on the REIT index have no expected direction, perhaps because the effects of these variables occur within a month. Therefore, we only focus on the impact of explained variables on the REIT index during the current period. In particular, we find that the coefficients for the stock index in each of the examined countries are significantly positive, indicating that there are consistent and significant positive impacts of the stock index on the REIT index in Japan, Singapore and China. The coefficients for the inflation rate in Japan, Singapore and China are significantly negative; thus, there are clearly negative impacts of the inflation rate on the REIT index in these three Asian countries. Moreover, the coefficients of the interest rate in Japan and Singapore are significantly negative, whereas this coefficient is insignificant in China. Thus, there may be a larger influence from the interest rate in Asian countries with larger market values of REITs.

The short-run elasticities in this study are estimated with the error correction models of equation (4), and the results of these estimations are reported in Table 5. In terms of the current period, the short-run dynamic coefficients of the stock index and the error correction term possess the correct signs and attain statistically significant levels. Specifically, the coefficients for the stock index are significantly positive in all three of these Asian countries, and the coefficients for the inflation rate are significantly negative in Singapore and China. The short-run coefficient for the inflation is non-significant in Japan possibly because Japan is a developed country and its inflation rate is high. The short-run increase in inflation rate in Japan tend to not significantly and negatively reduce the demand in Japanese investors for REITs, which leads not to negatively affect its REIT index in the short-run period. More importantly, the coefficients for the error correction term are significantly negative, implying that the reverting mechanism for sustaining the cointegration relationship between the macroeconomic variables and

${ }^{7}$ Our results for the long-run elasticities, based on the use of the SBC to select the optimal lag order, are reported in Table 4. the REIT index is extremely relevant in all three Asian countries ${ }^{8}{ }^{8}$.

\subsection{The results of the granger non-causality test.}

The results of Granger non-causality tests of Toda and Yamamoto (1995) are displayed in Table 6. We determine that there is a significant unidirectional relationship in which inflation rate shifts cause REIT index changes for $\mathrm{d}=2$ in Japan and for $\mathrm{d}=1$ and $\mathrm{d}=2$ in Singapore. This result implies that the REIT index in Japan and Singapore is dependent on the inflation rate in these countries. In particular, the REIT index in Japan and Singapore decreases if the inflation rate in these nations continuously increases. There is the non-significant causation from the inflation rate to the REIT index in China possibly because the REITs in China have smaller market value and shorter history than the REITs in Japan and Singapore. In terms of the causal relationship, the inflation rate tends to not significantly cause the REIT index in China. In addition to the inflation rate, Table 6 demonstrates that there is a significant unidirectional relationship in which stock index movements cause REIT index changes for $\mathrm{d}=2$ in Singapore. This finding implies that an increase in the stock index may lead to an increase in the REIT index in Singapore. There are the nonsignificant causations from the stock index to the REIT index in Japan and China. The former can be the reason that the investors in the Japanese stock market can have more investing choices due to the fact that Japan is a developed country. The latter can be the reason that Chinese REITs have smaller market value and shorter history then the two Asian countries, which leads to the smaller impact. However, we find no evidence of causality between the interest rate and the REIT index for any of these three Asian nations. There are no significant causations from the interest rate to the REIT index in Japan, Singapore and China possibly because the interest rates in the three Asian countries are lower than other countries. The reason leads to the nonsignificant incentive from the reduction of interest rate to increase in the investment of REIT markets.

\section{Conclusion}

This paper first uses the ARDL bounds test developed by Pesaran et al. (2001) to examine whether a cointegration equilibrium exists between the REIT index and the macroeconomic variables of interest rate, inflation rate and stock index in three Asian countries. Our results provide evidence that there is a long-run equilibrium between these three macro-

\footnotetext{
${ }^{8}$ In addition, there are consistently higher adjusted $R^{2}$ values in the error correction models for all of the examined countries, indicating that the models are fitted appropriately. Our results from the JB and BG tests reveal that the residuals are normally distributed and demonstrate no evidence of autocorrelation.
} 
economic variables and the REIT index in China and Singapore, but no similar equilibrium exists for Japan. This paper then uses a long-run ARDL model to determine that the stock index has a significantly positive relationship to the REIT index in these three countries, the inflation rate has a significantly negative relationship to the REIT index in Japan, Singapore and China, and the interest rate has a significantly negative relationship to the REIT index in Japan and Singapore. In addition, we use the ECM to confirm that the feedback mechanism of reverting to the long-run relationship is valid in all three Asian countries. Finally, we adopt the Granger non-causality test by Toda and Yamamoto (1995) to examine the causal relationships between the examined macroeconomic variables and the REIT index in each of these three countries. Our results demonstrate the existence of a unidirectional relationship in which inflation rate shifts cause REIT index changes in Japan and Singapore. In addition, we find evidence of a unidirectional relationship in which stock index movements cause REIT index changes in Singapore. Hence, our re- sults show that a wealth effect only exists in Singapore.

Our contribution can be summarized as the followings. First, the ARDL bounds test can examine the cointegration between macroeconomic variables and the REIT index in a manner that overcomes potential problems that may arise due to the uncertain results of the unit root test, endogeneity issues, and a small sample size. Second, the long-run ARDL model and the ECM allow us to simultaneously analyse the long- and short-run flexibility of the examined macroeconomic variables on the REIT index. Third, the Granger non-causality test can examine causation regardless of whether the examined variables are I (0) or I (1) or what the cointegration properties of these variables may be. Our contribution to the extant literature involves the combination of these multiple methods in a way that clarifies the influence of the examined macroeconomic factors on the REIT index in these three Asian countries, which have high REIT market values and rapid REIT growth. This result provides a reference for REIT investments for investors in these countries.

\section{References}

1. Adrangi, B., Chatrath, A., Raffiee, K. (2004), REIT investments and hedging against inflation, Journal of Real Estate Portfolio Management, 10 (2), pp. 97-112.

2. Allen, M.T., Madura, J., Springer, T.M. (2000), REIT characteristics and the sensitivity inflation, Journal of Real Estate Finance and Economics, 21 (2), pp. 141-152.

3. Atkinson, A.B. (1969), The timescale of economic models: how long is the long run? Review of Economic Studies 137-151.

4. Bredin, D., O`Reilly, G., Stevenson, S. (2008), Monetary policy \& real estate investment trusts. Banking \& Finance Subject Area UCD Business Schools WP08/12.

5. Caporale, G.M., Pittis, N. (1999), Efficient estimation of cointegrating vectors and testing for causality in vector autoregressions. Journal of Economic Surveys 13, pp. 3-35.

6. Chatrath, A., Liang, Y. (1998), REITs and inflation: a long-run perspective. Journal of Real Estate Research 16(3), 311-325.

7. Chan, K.C., Hendershott, P.H., Sanders, A.B. (1990), Risk and return on real estate: evidence from equity REITs. Real Estate Economics 18(2), 97-112.

8. Chang, K.L., Chen, N.K., Leung, C.K.Y. (2011), Monetary policy, term structure and asset return: comparing REIT, housing and stock. Journal of Real Estate Finance and Economics 43, pp. 221-257.

9. Chen, D., Gao, Y., Kaul, M., Leung, C.K.Y., Tsang, D. (2014), The role of sponsor and external management on the capital structure of Asian-Pacific REITs: the case of Australia, Japan, and Singapore. Forthcoming in International Real Estate Review.

10. Chen, K.C., Tzang, D.D. (1988), Interest-rate sensitivity of real estate investment trusts. Journal of Real Estate Research 3(1), pp. 13-22.

11. Chen, M.C., Peng, C.L., Shyu, S.D., Zeng, J.H. (2012), Market states and the effect on equity REIT returns due to changes in monetary policy stance. Journal of Real Estate Finance and Economics 45, pp. 364-382.

12. Chen, N.K., Leung, C.K.Y. (2008), Asset price spillover, collateral and crises: with an application to property market policy. Journal of Real Estate Finance and Economics 37(4), pp. 351-385.

13. Chen, S.J., Hsieh, C.H., Jordan, B.D.(1997), Real estate and the arbitrage pricing theory: macrovariables vs. derived factors. Journal of Real Estate Finance and Economics 125, pp. 505-523.

14. Conner, P., Liang, Y. (2005), The complex interaction between real estate cap rates and interest rates. Briefings in Real Estate Finance 4(3), pp.185-197.

15. Davis, E.P., Zhu, H. (2005), Commercial property prices and bank performance. BIS Working Paper.

16. Devaney, M. (2001). Time varying risk premia for real estate investment trusts: a GARCH-M model.The Quarterly Review of Economics and Finance 41, pp. 335-346. 
17. Downs, D.H., Fung, H.G., Gary, A.P., Yau, J. (2003), The linkage of REIT income- and price-returns with fundamental economic variables. The Journal of Alternative Investments (summer), pp. 39-50.

18. Dubach, N.A. (2013), Finance capital launches an assault on Chinese real estate. China Perspectives 2, pp. 29-39.

19. Emran, M.H., Shilip, F., Alam, M.I. (2007). Economic liberalisation and price response of aggregate private investment, time series evidence from India. Canadian Journal of Economics 40, pp. 914-934.

20. Ennis, R., Burik, P. (1991), Pension fund real estate investment under a simple equilibrium pricing model. Financial Analyst Journal 47(3), pp. 20-30.

21. Ewing, B.T., Payne, J.E. (2005), The response of real estate investment trust returns to macroeconomic shocks. Journal of Business Research 58(3), pp. 293-300.

22. Glascock, J.L., Lu, C., So, R.W. (2002), REIT returns and inflation: perverse or reverse causality effects? Journal of Real Estate Finance and Economics 24(3), pp. 301-317.

23. Gyourko, J., Linneman, P. (1998). Owner-occupied homes, income-producing properties, and reits as inflation hedges: empirical findings. Journal of Real Estate Finance and Economics, 1(4), pp. 347-372.

24. Gyourko, J., Keim, D. (1992), What does the stock market tell us about real estate returns? AREUEA Journal 20, pp. 457-485.

25. Harris, R. (1995), Using cointegration analysis in econometric modeling. (Prentence Hall/Harvester Wheatsheaf, London).

26. He, L.T., Webb, J.R., Myer, F.C. (2003), Interest rate sensitivities of REIT returns. International Real Estate Review 6 (1), pp. 1-21.

27. Hideki, N., 2007. An analysis of the relationship between US REIT returns. Economics Bulletin 13(1), pp. 1-7.

28. Hoesli, M., Reka, K. (2015), Contagion channels between real estate and financial markets. Real Estate Economics 43(1), pp.101-138.

29. Huang, M., Wu, C.C. (2015). Economic benefits and determinants of extreme dependences between REIT and stock returns. Review of Quantitative Finance and Accounting 44, pp. 299-327.

30. Huang, M., Wu, C.C., Liu, S.M., Wu, C.C. (2016), Facts of fates of investors' losses during crises? Evidence from REIT-stock volatility and tail dependence structures. International Review of Economics and Finance 42, pp. 54-71.

31. Jacob, D., Zisler, R. (1994), Real estate inflation and interest rates.New York: Nomura Securities International Inc.

32. Johansen, S., 1988. Statistical analysis of cointegrating vectors. Journal of Economic Dynamics and Control 12 , pp. 231-54.

33. Kan, K., Kwong, S.K.S., Leung, C.K.Y. (2004), The dynamics and volatility of commercial and residential property prices: theory and evidence. Journal of Regional Science 44(1), pp. 95-123.

34. Karolyi, G.A., Sanders, A.B. (1998), The variation of economics risk premiums in real estate returns. Journal of Real Estate Finance and Economics 15(3), pp. 245-262.

35. Kim, J.W., Leatham, D.J., Bessler, D.A. (2007), REITs' dynamic under structural change with unknown break points. Journal of Housing Economics 16(1), pp. 37-58.

36. Li, Y., Wang, K. (1995), The predictability of REIT returns and market segmentation. The Journal of Real Estate Research 10(4), pp. 471-482.

37. Lin, Y. (2004), Three essays on real estate investment trusts. Business Administration-Finance, Doctor of Philosophy, Old Dominion University.

38. Liu, C., Mei, J. (1992), The predictability of returns on equity REITs and their co-movements with other assets. Journal of Real Estate Finance and Economics 5(4), pp. 401-418.

39. Liow, K.H. (2006), Dynamic relationship between stock and property markets. Applied Financial Economics 16(5), 371-376.

40. Liow, K.H., Newell, G. (2012). Investment dynamics of the greater China securitized real estate markets. Journal of Real Estate Research 34(3), pp. 399-428.

41. Liow, K.H., Zhou, X., Qing, Y. (2015). Correlation dynamics and determinants in international securitized real estate markets. Real Estate Economics 43 (3), pp. 537-585.

42. Lu, C., So, R.W. (2001). The relationship between REITs returns and inflation: a vector error correction approach. Review of Quantitative Finance and Accounting 16, pp. 103-115.

43. Mah, J.S. (2000), An empirical examination of the disaggregated import demand of Korea - the case of information technology products. Journal of Asian Economics 11, pp. 237-44.

44. McCue, T.E., Kling, J.L. (1994), Real estate returns and the macroeconomic: some empirical evidence from real estate investment trust data. Journal of Real Estate Research 9(3), pp. 277-287.

45. Mengden, A., Hartzell, D. (1986), Real estate investment trusts-are they stocks or real estate? New York: Salomon Brother Inc.

46. Michael, C.H., Quek, Seow, E.O. (2008), Securitising China real estate: a tale of two China-centric REITs. Journal of Property Investment \& Finance 26(3), pp.247-274.

47. Mueller, G.R., Pauley, K.R. (1995), The effect of interest-rate movements on real estate investment trusts. The Journal of Real Estate Research 10(3), pp. 319-325.

48. Ooi, J.T.L., Liow, K.H. (2004), Risk-Adjusted performance of real estate stocks: evidence from developing markets. Journal of Real Estate Research 26(4), pp. 371-395.

49. Payne, J.E. (2003), Shocks to macroeconomic state variable and the risk premium of REITs. Applied Economic Letters 10(11), pp. 671-677. 
50. Peiser, R.B., Smith, L. (1985). Homeownership returns, tenure choice and inflation. AREUEA Journal 13, pp. 343-360.

51. Pesaran, H., Shin, Y., Smith, R. J. (2001), Bounds testing approaches to the analysis of level relationship. Journal of Applied Econometrics 16, 289-326.

52. Peterson, J.D., Hsieh, C.H. (1997). Do common risk factors in the returns on stocks and bonds explain returns on REITs? Real Estate Economics 25(1), pp. 321-345.

53. Ross, S., Zisler, R. (1991), Risk and return in real estate. Journal of Real Estate Finance and Economics 4(3), $175-190$.

54. Ross, S., Zisler, R. (1987 a), Managing real estate portfolios part 2: risk and returns real estate. New York: Glodman Sachs.

55. Ross, S., Zisler, R. (1987 b), Managing real estate portfolios part 3: a close look at equity real estate risk. New York: Glodman Sachs.

56. Simpson, M.W., Ramchander, S., Webb, J.R. (2007), The asymmetric response of equity REIT returns to inflation. Journal of Real Estate Finance and Economics 34(4), pp. 513-529.

57. Swanson, Z., Theis, J., Casey, K.M. (2002), REIT risk premium sensitivity and internet rates. Journal of Real Estate Finance and Economics 24(3), pp. 319-330.

58. Thao, H. (2006), Europe primed for REITs. Pensions \& Investment 34(12), pp. 1-39.

59. Toda, H.Y., Yamamoto, T. (1995), Statistical inference in vector autoregression with possibly integrated processes. Journal of Econometrics 66, pp. 225-250.

60. Wang, H., Sun, Y., Chen, Y. (2009), Special considerations for designing pilot REITs in China. Journal of Property Investment \& Finance 27 (2), pp. 140-161.

61. West, T., Worthington, A.C. (2006), Macroeconomic risk factors in Australian commercial real estate, listed property trust and property sector stock returns: a comparative analysis using GARCH-M. Journal of Financial Management of Property and Construction 11(2), August 2006, pp. 21-31.

62. Zapata, H.O., Rambaldi, A.N. (1997), Monte Carlo evidence on cointegration and causation. Oxford Bulletin of Economics and Statistics 59(2), pp. 285-298.

\section{Appendix}

Table 1. The number and value of REITs in the markets of the examined Asian countries

\begin{tabular}{|l|c|c|c|c|c|}
\hline \multicolumn{1}{|c|}{ Country } & Year established & Number of REITs & $\begin{array}{c}\text { Value of REITs } \\
(\mathrm{bn} €)\end{array}$ & $\begin{array}{c}\text { Proportion of Asian REIT } \\
\text { Markets }(\%)\end{array}$ & $\begin{array}{c}\text { Proportion of Global REIT } \\
\text { Markets }(\%)\end{array}$ \\
\hline Japan & 2001 & 36 & 21.2 & 46.19 & 5.4 \\
\hline Singapore & 2001 & 21 & 14.5 & 31.59 & 3.7 \\
\hline China & 2006 & 6 & 4.4 & 9.57 & 1.1 \\
\hline
\end{tabular}

Source: EPRA REIT survey, 2010

Table 2. Summary statistics

\begin{tabular}{|c|c|c|c|c|c|c|c|}
\hline Singapore & Mean & Max. & Mini. & Std. Dev. & Skewness & Kurtosis & Jarque-Bera \\
\hline R & 0.5714 & 17.3847 & -32.0226 & 7.0580 & -1.2190 & 6.8156 & $89.6986^{* * *}$ \\
\hline S & 0.8786 & 21.1553 & -36.6770 & 8.0891 & -1.2981 & 6.9650 & $98.2694^{* * *}$ \\
\hline IT & 12.1183 & 408.8000 & -564.7100 & 146.6489 & -1.0388 & 5.9927 & $58.0660^{* * *}$ \\
\hline IF & 0.2285 & 2.0459 & -0.9730 & 0.5837 & 0.3343 & 3.0755 & 1.9807 \\
\hline Japan & Mean & Max. & Mini. & Std. Dev. & Skewness & Kurtosis & Jarque-Bera \\
\hline R & 0.0349 & 12.7262 & -23.2047 & 5.4713 & -1.0015 & 5.6944 & $60.5837^{* * *}$ \\
\hline S & -0.0749 & 15.7837 & -44.4935 & 7.0352 & -1.9722 & 13.8860 & $720.5913^{* * *}$ \\
\hline IT & 0.0019 & 0.1900 & -0.1250 & 0.0448 & 1.0955 & 7.5391 & $136.5441^{* * *}$ \\
\hline IF & -0.0170 & 0.7897 & -0.8811 & 0.2932 & -0.1092 & 2.9214 & 0.2896 \\
\hline China & Mean & Max. & Mini. & Std. Dev. & Skewness & Kurtosis & Jarque-Bera \\
\hline R & -0.7988 & 39.8707 & -35.1794 & 11.8867 & 0.0529 & 6.0679 & $20.0246^{* * *}$ \\
\hline S & -0.9622 & 16.0607 & -25.7797 & 8.6402 & -0.7775 & 4.0875 & $7.6507^{* *}$ \\
\hline IT & -0.0389 & 0.6650 & -0.8900 & 0.3233 & -0.1577 & 3.1817 & 0.2817 \\
\hline IF & 0.3255 & 3.2722 & -2.9617 & 1.3476 & -0.1823 & 2.8416 & 0.3359 \\
\hline
\end{tabular}

Note: 1. Each variable was transformed by taking its natural logarithm and its first difference prior to analysis. 2. R denotes the REIT index, $\mathrm{S}$ denotes the stock index, IT denotes the interest rate, and IF denotes the inflation rate. 3. $* *$ and $* * *$ indicate the $5 \%$ and $1 \%$ significance levels, respectively. 
Table 3. The results of the bounds test for cointegration

\begin{tabular}{|c|c|c|c|c|c|c|c|}
\hline \multirow{2}{*}{ Country } & \multirow{2}{*}{$\begin{array}{l}\text { Computed F- } \\
\text { statistic }\end{array}$} & \multirow{2}{*}{\multicolumn{2}{|c|}{$\frac{10 \% \text { Critical }}{I(0) I(1)}$}} & \multirow{2}{*}{\multicolumn{2}{|c|}{$\frac{5 \% \text { Critical }}{I(0) I(1)}$}} & \multirow{2}{*}{ ARDLspecification } & \multirow{2}{*}{$\begin{array}{c}\text { Conclusion(the hypothesis of no cointe- } \\
\text { gration) }\end{array}$} \\
\hline & & & & & & & \\
\hline \multicolumn{8}{|c|}{ Panel A: AIC } \\
\hline Japan & 3.05647 & 2.72 & 3.77 & 3.23 & 4.35 & $1,3,1,3$ & Accept \\
\hline China & 6.00723 & 2.72 & 3.77 & 3.23 & 4.35 & $4,3,4,4$ & Reject \\
\hline Singapore & 6.06052 & 2.72 & 3.77 & 3.23 & 4.35 & $1,1,2,2$ & Reject \\
\hline \multicolumn{8}{|c|}{ Panel B: SBC } \\
\hline Japan & 2.09743 & 2.72 & 3.77 & 3.23 & 4.35 & $1,1,1,1$ & Accept \\
\hline China & 5.5653 & 2.72 & 3.77 & 3.23 & 4.35 & $4,2,4,1$ & Reject \\
\hline Singapore & 6.06052 & 2.72 & 3.77 & 3.23 & 4.35 & $1,1,2,2$ & Reject \\
\hline
\end{tabular}

Table 4. The results of the long-run ARDL model

\begin{tabular}{|c|c|c|c|}
\hline \multirow{2}{*}{ Variable } & Japan-(1,1,0,0) & Singapore- $(1,1,0,0)$ & China- $(1,0,0,1)$ \\
\hline & Coeff (T-Stat) & Coeff (T-Stat) & Coeff (T-Stat) \\
\hline Constant & $4.092(1.515)$ & $0.5873^{\star *}(2.443)$ & $-5.8425^{*}(-1.9256)$ \\
\hline$S$ & $0.4503^{* * *}(8.013)$ & $0.8836^{\star * *}(34.194)$ & $0.7673^{* * *}(6.138)$ \\
\hline$S\{1\}$ & $-0.3679^{\star * *}(-5.997)$ & $-0.5926^{\star \star *}(-9.953)$ & \\
\hline IT & $-0.0247^{\star}(-1.779)$ & $-0.00003^{\star \star *}(-3.669)$ & $-0.0521(-1.626)$ \\
\hline IF & $-1.0220 *(-1.737)$ & $-0.2809^{\star \star \star}(-3.895)$ & $-2.6209^{* * *}(-2.916)$ \\
\hline $\mathrm{IF}\{1\}$ & & & $2.7705^{\star \star *}(3.171)$ \\
\hline$R\{1\}$ & $0.9450^{* * *}(31.754)$ & $0.7301^{* * *}(12.357)$ & $0.6300^{* * *}(9.198)$ \\
\hline
\end{tabular}

Note: 1.R denotes the REIT index, S denotes the stock index, IT denotes the interest rate, and IF denotes the inflation rate. 2. ***, $* *$, and $*$ indicate significance at the $1 \%, 5 \%$, and $10 \%$ levels, respectively. 3 . Numbers in ( ) indicate t-statistics.

Table 5. The results of the error correction model

\begin{tabular}{|c|c|c|c|}
\hline \multirow{2}{*}{ Variable } & Japan-(1,0,0,0) & Singapore- $(1,0,0,0)$ & China- $(1,1,0,0)$ \\
\hline & Coeff(T-Stat) & Coeff(T-Stat) & Coeff(T-Stat) \\
\hline Constant & $0.0011(0.296)$ & $-0.0004(-0.220)$ & $0.0052(0.484)$ \\
\hline $\operatorname{Ecm}\{1\}$ & $-0.0642^{* *}(-2.154)$ & $-0.2865^{* * *}(-4.44)$ & $-0.3998^{* * *}(-3.599)$ \\
\hline $\mathrm{DR}\{1\}$ & $0.2038^{* * *}(2.915)$ & $0.0057(0.239)$ & $0.0904(0.718)$ \\
\hline DS & $0.4854^{* \star *}(8.649)$ & $0.8468^{* * *}(23.044)$ & $0.6084^{* * *}(4.255)$ \\
\hline $\mathrm{DS}\{1\}$ & & & $0.0200(0.105)$ \\
\hline DIT & $0.0017(0.020)$ & $-0.00001(-0.747)$ & $-0.0156(-0.399)$ \\
\hline DIF & $0.4121(0.316)$ & $-0.5269^{*}(-1.884)$ & $-3.0837^{\star * *}(-3.238)$ \\
\hline R-Bar^2 & 0.397 & 0.9465 & 0.6124 \\
\hline F-statistics & $17.692[0.000]$ & $365.3321[0.00]$ & $13.905[0.000]$ \\
\hline DW & 2.062 & 2.0139 & 2.1005 \\
\hline JB test & $8.539[0.014]$ & $0.3527[0.838]$ & $1.485[0.476]$ \\
\hline BG test & $0.506[0.477]$ & $0.191[0.662]$ & $0.414[0.520]$ \\
\hline
\end{tabular}

Note: 1.R denotes the REIT index, S denotes the stock index, IT denotes the interest rate, and IF denotes the inflation rate. These variables are all made the first difference (denoted by D). Ecm denotes the error correction term. 2. ***, **, and * indicate significance at the 1\%,5\%, and 10\% levels, respectively. 3. Numbers in ( ) indicate t-statistics, and Numbers in [ ] mean p-value. 
Table 6. The results of the Granger non-causality tests of Toda and Yamamoto (1995)

\begin{tabular}{|c|c|c|c|c|c|c|}
\hline \multirow[t]{2}{*}{ China } & \multicolumn{2}{|c|}{$D=0$} & \multicolumn{2}{|c|}{$D=1$} & \multicolumn{2}{|c|}{$D=2$} \\
\hline & Chi-Squared & $p$-value & Chi-Squared & $p$-value & Chi-Squared & $p$-value \\
\hline$S=>R$ & 0.7042 & 0.4014 & 1.9728 & 0.3729 & 4.2606 & 0.2347 \\
\hline$I T=>R$ & 0.1456 & 0.7028 & 0.3738 & 0.8295 & 1.6765 & 0.6422 \\
\hline $\mathrm{IF}=>\mathrm{R}$ & 0.0000 & 0.9999 & 0.5761 & 0.7497 & 1.6161 & 0.6557 \\
\hline$R \Rightarrow S$ & 2.7014 & 0.1003 & 3.2467 & 0.1972 & 4.2340 & 0.2373 \\
\hline$R=>1 T$ & $3.4890^{*}$ & 0.0618 & 3.2713 & 0.1948 & 1.8464 & 0.6049 \\
\hline$R=>I F$ & $3.4649^{*}$ & 0.0627 & 4.1156 & 0.1277 & 2.9779 & 0.3950 \\
\hline \multirow[t]{2}{*}{ Japan } & \multicolumn{2}{|c|}{$D=0$} & \multicolumn{2}{|c|}{$D=1$} & \multicolumn{2}{|c|}{$D=2$} \\
\hline & Chi-Squared & $p$-value & Chi-Squared & $p$-value & Chi-Squared & $\mathrm{p}$-value \\
\hline$S=>R$ & 0.0020 & 0.9646 & 1.7422 & 0.4185 & 1.2100 & 0.7506 \\
\hline$I T=>R$ & 0.1320 & 0.7164 & 0.4959 & 0.7804 & 4.7135 & 0.1940 \\
\hline $\mathrm{IF}=>\mathrm{R}$ & 1.4202 & 0.2334 & 3.3417 & 0.1881 & $12.911^{* * *}$ & 0.0048 \\
\hline$R=>S$ & 1.4194 & 0.2335 & 2.3807 & 0.3041 & 1.4188 & 0.7011 \\
\hline$R=>\mid T$ & 0.1512 & 0.6974 & 0.7264 & 0.6954 & 1.4542 & 0.6929 \\
\hline $\mathrm{R}=>\mathrm{IF}$ & 0.1012 & 0.7505 & 0.4609 & 0.7942 & 2.4783 & 0.4792 \\
\hline \multirow[t]{2}{*}{ Singapore } & \multicolumn{2}{|c|}{$D=0$} & \multicolumn{2}{|c|}{$D=1$} & \multicolumn{2}{|c|}{$D=2$} \\
\hline & Chi-Squared & $p$-value & Chi-Squared & p-value & Chi-Squared & $p$-value \\
\hline$S=>R$ & 2.1880 & 0.1391 & 3.7460 & 0.1537 & $6.5325^{\star}$ & 0.0884 \\
\hline IT => R & 0.0724 & 0.7879 & 0.2296 & 0.8915 & 2.6083 & 0.4560 \\
\hline $\mathrm{IF}=>\mathrm{R}$ & $7.3819^{* * *}$ & 0.0066 & $9.0545^{* *}$ & 0.0108 & $12.9051^{* * *}$ & 0.0048 \\
\hline$R=>S$ & 0.8441 & 0.3582 & 1.7253 & 0.4220 & 3.4405 & 0.3286 \\
\hline$R=>I T$ & 0.2888 & 0.5910 & 0.7361 & 0.6921 & 1.0083 & 0.7993 \\
\hline$R=>I F$ & 0.3833 & 0.5359 & 0.4154 & 0.8125 & 2.2702 & 0.5183 \\
\hline
\end{tabular}

Note: $1 . \mathrm{R}$ denotes the REIT index, $\mathrm{S}$ denotes the stock index, IT denotes the interest rate, and IF denotes the inflation rate.2. ***, $* *$, and $*$ indicate significance at the $1 \%, 5 \%$, and $10 \%$ levels, respectively. 